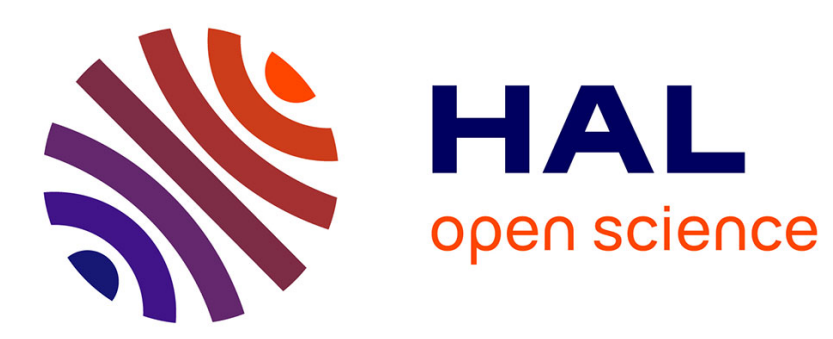

\title{
Organic carbon burial forcing of the carbon cycle from Himalayan erosion
}

\author{
Christian France-Lanord, Louis Derry
}

\section{To cite this version:}

Christian France-Lanord, Louis Derry. Organic carbon burial forcing of the carbon cycle from Himalayan erosion. Nature, 1997, 390 (6655), pp.65-67. 10.1038/36324 . hal-02149397

\section{HAL Id: hal-02149397 \\ https://hal.science/hal-02149397}

Submitted on 6 Jun 2019

HAL is a multi-disciplinary open access archive for the deposit and dissemination of scientific research documents, whether they are published or not. The documents may come from teaching and research institutions in France or abroad, or from public or private research centers.
L'archive ouverte pluridisciplinaire HAL, est destinée au dépôt et à la diffusion de documents scientifiques de niveau recherche, publiés ou non, émanant des établissements d'enseignement et de recherche français ou étrangers, des laboratoires publics ou privés. 
France-Lanord, C., \& Derry, L. A. (1997). Organic carbon burial forcing

of the carbon cycle from Himalayan erosion. Nature, 390(6655), 65-

67. http://doi.org/10.1038/36324

\title{
Organic carbon burial forcing of the carbon cycle from Himalayan erosion
}

\author{
Christian France-Lanordab \& Louis A. Derry ${ }^{b}$ \\ a Centre de Recherches Pétrographiques et Géochimiques, CNRS, BP20 54501 Vandoeuvre-les-Nancy, France \\ b Cornell University, Department of Geological Sciences, Ithaca, New York 14853, USA
}

\begin{abstract}
Weathering and erosion can affect the long-term ocean-atmo- sphere budget of carbon dioxide both through the consumption of carbonic acid during silicate weathering and through changes in the weathering and burial rates of organic carbon ${ }^{1-4}$. Recent attention has focused on increased silicate weathering of tectoni- cally uplifted areas in the India-Asia collision zone as a possible cause for falling atmospheric $\mathrm{CO}_{2}$ levels in the Cenozoic era ${ }^{5-7}$. The chemistry of Neogene sediments from the main locus of sedimentary deposition for Himalayan detritus, the Bengal Fan, can be used to estimate the sinks of $\mathrm{CO}_{2}$ from silicate weathering and from the weathering and burial of organic carbon resulting from Himalayan uplift. Here we show that Neogene $\mathrm{CO}_{2}$ con- sumption from the net burial of organic carbon during Himala- yan sediment deposition was 2-3 times that resulting from the weathering of Himalayan silicates. Thus the dominant effect of Neogene Himalayan erosion on the carbon cycle is an increase in the amount of organic carbon in the sedimentary reservoir, not an increase in silicate weathering fluxes.
\end{abstract}

Silicate weathering is typically incongruent, yielding both a solute and a secondary mineral phase, so direct evidence of chemical weathering can be found in the record of secondary minerals in sedimentary basins. The Bengal Fan and Ganges-Brahmaputra (GB) delta contain a huge volume of sediment derived from erosion of the India-Asia collision zone, with $6 \times 10^{6} \mathrm{~km}^{3}$ deposited in the past $20 \mathrm{Myr}$ (ref. 8). Isotopic data for $\mathrm{Nd}, \mathrm{Sr}$ and O from Bengal Fan sediments show that the source for over $80 \%$ of the detritus since 20 Myr ago has been the high-grade metasedimentary rocks of the High Himalayan crystalline $(\mathrm{HHC})$ sequence ${ }^{9}$. Clastic and carbonate sediments of the Precambrian Lesser Himalaya (LH) and Palaeozoic-Mesozoic Tethyan Himalaya (TH) are the other important sources of sediment to the Bengal Fan during the Neogene. 
Carbon dioxide consumption from silicate weathering can be represented schematically by:

$\mathrm{CaSiO}_{3}+2 \mathrm{CO}_{2}+2 \mathrm{H}_{2} \mathrm{O} \rightarrow \mathrm{Ca}^{2+}+2 \mathrm{HCO}-+\mathrm{H}_{4} \mathrm{SiO}_{4} \rightarrow \mathrm{CaCO}_{3}+\mathrm{SiO}_{2}+\mathrm{CO}_{2}+2 \mathrm{H}_{2} \mathrm{O}$

where $1 \mathrm{~mol}$ of $\mathrm{CO}_{2}$ is sequestered as marine carbonate for each $\mathrm{mol} \mathrm{Ca} \mathrm{(or} \mathrm{Mg}$ ) derived from silicate dissolution. Weathering of $\mathrm{Na}$ and $\mathrm{K}$ silicates contributes a smaller fraction to the weathering $\mathrm{CO}_{2}$ sink because alkalis can exchange for $\mathrm{Ca}: \pm \mathrm{Mg}$ adsorbed on detrital clays in estuarine zones, and during alteration of the oceanic crust ${ }^{10,11}$. We estimate the $\mathrm{CO}_{2}$ consumption from silicate weathering by compar- ing the chemistry of the weathered sediments deposited in the Bengal Fan with the chemistry of their unaltered Himalayan source rocks. The comparison slightly overestimates $\mathrm{CO}_{2}$ consumption because any base cations released by weathering with strong acids (such as $\mathrm{H}_{2} \mathrm{SO}_{4}$ ) are still included in this $\mathrm{CO}_{2}$ consumption budget. To represent the source of Bengal Fan sediment we use a composite of 99 samples from outcrops in the HHC (Table 1). Adding samples from the $\mathrm{LH}$ and $\mathrm{TH}$ strata to the average value for Himalayan source rocks does not change the estimated weathering fluxes significantly, because the combined contribution from these units to the sediment flux in the Bengal Fan is $<20 \%$, and all three (meta)sedimentary units are chemically similar. We analysed a subset of HHC samples from Central Nepal for total organic carbon (Corg) contents. Metamorphic rocks of the HHC average 0:05: $: \pm: 03 \%$ Corg. Sediments of the Lesser Himalaya also have low Corg contents, $<0.10 \%$, except for rare black shale beds. Sediments of the Tethyan Himalaya include both carbonates and Palaeozoic clastic sediments with low $\mathrm{C}_{\text {org }}$ values, and some Mesozoic shales with up to $1.5 \% \mathrm{C}_{\text {org }}$ (ref. 13). We estimate a volumeweighted mean $\mathrm{C}_{\text {org }}$ content of $0.10: \pm 0: 05 \%$ for the source rocks of Bengal Fan sediment.

We sampled Himalayan-derived sediments from late Pleistocene to mid-Miocene age recovered from the distal Bengal Fan on Leg

116 of the Ocean Drilling Program ${ }^{14}$. The sediments were chosen to

represent a range of weathering intensities based on clay mineralogy ${ }^{15}$. Before $7 \mathrm{Myr}$ and after $1 \mathrm{Myr}$ ago the clay mineral assemblage ( $<2 \mathrm{~J} . \mathrm{m}$ size fraction) in the Bengal Fan is dominantly illite plus chlorite (the IC assemblage). From 7 to $1 \mathrm{Myr}$, clays in the Fan are dominantly pedogenic smectite and kaolinite (SK assemblage), reflecting more intense weathering in the GB floodplain ${ }^{16}$. The fine-grained, SK sediments from the Bengal Fan are the most intensely weathered Himalayan sediments, and are less abundant than the IC sediments. Before dissolution, whole rock samples were disaggregated in distilled $\mathrm{H}_{2} \mathrm{O}$, then leached with $10 \%$ acetic acid to remove minor carbonates (diagenetic, biogenic and detrital). Leaching of diagenetic carbonate removes some $\mathrm{Ca}$ and $\mathrm{Mg}$ derived from alteration of detrital silicates, although $\mathrm{Sr}$ isotopic data on the carbonate fraction show that most cations are derived from sea water. Ion exchange of $\mathrm{H}^{+}$for adsorbed cations on 
clays may also release some silicate-derived cations. Thus our technique probably causes us to overestimate the silicate-derived alkalinity flux.

We normalized the major element concentrations of $\mathrm{HHC}$ source material and Bengal Fan sediment to their $\mathrm{Al}_{2} \mathrm{O}_{3}$ contents, on the assumption that during low-intensity weathering characteristic of the Himalayan drainage, aluminium is conservative. The global mean transport of dissolved $\mathrm{Al}$ is estimated to be $<0.1 \%$ of suspended load transport ${ }^{17}$, making this a reliable assumption. The differences in ratios of major cations to $\mathrm{Al}_{2} \mathrm{O}_{3}$ between the $\mathrm{HHC}$ and Bengal Fan sediments can result from weathering losses, mineral sorting or residual enrichment of insoluble cations. Dis- solved silica transport in the modern Ganges (from all sources) is about $0.3 \%$ of suspended load transport ${ }^{18}$, indicating that dissolu- tion of quartz is minor. Low $\mathrm{SiO}_{2} / \mathrm{Al}_{2} \mathrm{O}_{3}$ in the sediments results from mineral sorting, as quartz is mechanically resistant and is transported less readily than finer-grained aluminosilicate minerals. If fine-grained silicates are preferentially transported to the distal Bengal Fan our estimate of alkalinity flux is too high, as the fine- grained material contains a higher proportion of weathered clay minerals. However, the fine-grained material is also enriched in $\mathrm{Mg}$, which tends to counteract this bias. Differences in the weathering intensity between the IC and SK sediments are apparent in the base cation $/ \mathrm{Al}_{2} \mathrm{O}_{3}$ ratios. IC sediments have lost little or no $\mathrm{K}_{2} \mathrm{O}$ and $\mathrm{MgO}$ relative to the $\mathrm{HHC}$ source rocks, and about half of their $\mathrm{Na}_{2} \mathrm{O}$ and $\mathrm{CaO}$. These results are in good agreement with analyses of modern soil profiles developed on Himalayan gneisses ${ }^{19}$. SK sedi- ments have lost some $\mathrm{MgO}$, about half of their $\mathrm{K}_{2} \mathrm{O}$ and $\mathrm{CaO}$, and much of their $\mathrm{Na}_{2} \mathrm{O}$. The mean $\mathrm{C}_{\text {org }}$ content of Bengal Fan sediments is $0.85 \%(n 1 / 4155)$, with the mean for IC sediments being $0.4 \%$, whereas the mean for SK sediments is $1.5 \%{ }^{20}$. Data from fan sediments in the region near the delta yield similar values to the distal fan, with mean $C_{\text {org }} 1 / 40: 90 \%$ (ref. 21 ), suggesting that any sorting effect on $\mathrm{C}_{\text {org }}$ contents is minor.

Consumption of $\mathrm{CO}_{2}$ due to Himalayan silicate weathering was calculated assuming that all $\mathrm{Mg}^{2+}$ and $\mathrm{Ca}^{2+}$ lost from the silicates forms marine carbonates. The fraction of $\mathrm{K}$ and $\mathrm{Na}$ involved in cation exchange reactions with sediments or the oceanic crust remains poorly known ${ }^{10,22}$. We conservatively estimate that $20 \%$ of $\mathrm{K}^{+}$and $30 \%$ of $\mathrm{Na}^{+}$in the global river flux exchanges for $\mathrm{Ca}: \pm \mathrm{Mg}$ and produces carbonates. Accounting for charge balance, $\mathrm{CO}_{2}$ consumption can be estimated from the base cation losses during Himalayan erosion:

$-\Delta \mathrm{CO}_{2}=\Delta \mathrm{Ca}+\Delta \mathrm{Mg}+0.10 \Delta \mathrm{K}+0.15 \Delta \mathrm{Na}$

We have ignored neoformation of marine clays ('reverse weath- ering'), which may be a significant sink for base cations23 and would lower the estimated $\mathrm{CO}_{2}$ consumption. Consumption of $\mathrm{CO}_{2}$ by silicate weathering is $0.17 \mathrm{~mol} \mathrm{~kg}-1$ for the less weathered IC sediments and $0.23 \mathrm{~mol} \mathrm{~kg}-1$ for the SK sediments. 
Similarly, we esti- mate the $\mathrm{CO}_{2}$ consumption from organic carbon (Corg) burial by comparing the Corg content of the clastic sediments in the Bengal Fan with the Corg content of their Himalayan source rocks. For IC sediments, this sink is about $0.27 \mathrm{~mol} \mathrm{CO}_{2} \mathrm{~kg}^{-1}$; for SK sediments the sink is $1.1 \mathrm{~mol} \mathrm{CO} \mathrm{kg}^{-1}$, 1.7 and 4.7 times their respective silicate weathering sinks (Fig. 1). The more intensely weathered SK sediments also have higher $\mathrm{C}_{\mathrm{org}}$ contents, more than offsetting the greater cation losses. These averages are representative of the range of sediment organic and inorganic chemistries in the Bengal Fan. We emphasize that this conclusion is based on a probable over- estimate of the magnitude of the silicate weathering flux for $\mathrm{CO}_{2}$ : our sample preparation and data analysis tends to bias this estimate towards high values. The result is independent of the magnitude of sediment fluxes past or present, because we have measured $\mathrm{CO} 2$ consumption by inorganic and organic sinks in the same samples. The fluxes of $\mathrm{CO} 2$ implied by these estimates can be compared with independent global estimates. For a mean suspended load flux of $8 \times 1011 \mathrm{~kg} \mathrm{yr}^{-1}$ (ref. 24) our data yield an average CO2 con- sumption by silicate weathering in the GB system of $0: 17 \times 10^{12} \mathrm{~mol}^{\mathrm{yr}^{-1}}$ during the Neogene. This flux is $2.6 \%$ of the current global silicate weathering sink for $\mathrm{CO}_{2}$ (ref. 2). The modern GB contributes $2.7 \%$ of the global river water discharge and $2.1 \%$ of the global riverine $\mathrm{SiO}_{2}$ flux ${ }^{18,22}$. Thus our estimates for both the long-term discharge-weighted $\mathrm{CO}_{2}$ consumption via silicate weath- ering and the modern discharge-weighted $\mathrm{SiO}_{2}$ flux in the $\mathrm{GB}$ system are near the current world average. Despite the huge erosional flux from the Himalaya, the silicate weathering sink for $\mathrm{CO}_{2}$ is modest on the global scale. The extreme relief of the Himalaya and the monsoon climate result in very rapid physical denudation and fast transport of sediment to the ocean. One result is a strongly weathering-limited system in which the kinetics of chemical weathering are slow relative to the transport time of eroded rock to the sea. Furthermore, Ca silicates are not abundant in the Himalaya, and the silicatederived alkalinity flux is largely in the form of $\mathrm{Na}$ and $\mathrm{K}$ cations which are inefficient sinks of $\mathrm{CO}_{2}$.

The data above yield an average Neogene rate of net growth (burial-weathering $>0$ ) of the sedimentary $\mathrm{C}_{\text {org }}$ reservoir of 0:58 $\times 10^{12} \mathrm{~mol} \mathrm{yr}{ }^{1}$ in the Himalayan-Bengal system. The net growth in the size of the global sedimentary $\mathrm{C}_{\text {org }}$ reservoir can be estimated from the marine carbon isotopic mass balance ${ }^{25}$. Our recent results from a $\mathrm{d}^{13} \mathrm{C}$ model ${ }^{26}$ yield a global average net flux to the sedimentary $\mathrm{C}_{\text {org }}$ reservoir of about $1: 1$ $X 10^{12} \mathrm{~mol}$ yr over the past $15 \mathrm{Myr}$. The results are not directly comparable because one value represents a regional flux, whereas the other represents a global flux. However, they are consistent, and suggest that $\mathrm{C}_{\text {org }}$ burial in excess of weathering in the Himalayan-Bengal system can contribute significantly to changes in the global $\mathrm{C}_{\text {org }}$ reservoir. Together with the Indus fan and the Indo-Gangetic plain, the Bengal Fan accounts for about $15 \%$ of the modern total burial flux of global $\mathrm{C}_{\text {org }}$ (ref. 20 ), so it is not surprising that any imbalance (burial-weathering $\neq 0$ ) in the Himalayan-Bengal $C_{\text {org }}$ budget could have had a global impact. Up to $90 \%$ of $\mathrm{C}_{\text {org }}$ burial takes place in continental margin sediments ${ }^{27}$, so any process that increases continental margin sedimentation significantly, such as erosion of a major orogen, may be expected to increase $\mathrm{C}_{\text {org }}$ burial and 
possibly amplify imbalances in the $\mathrm{C}_{\text {org }}$ budget. Rapid erosion and the high suspended load of the GB system help drive $\mathrm{C}_{\text {org }}$ burial rates high enough to perturb the global carbon cycle significantly. Erosion of a major orogenic belt such as the Himalaya creates a large amount of mineral surface area, which is a strong control on organic carbon burial in continental margin settings ${ }^{28}$.

Recent work on the evolution of the global climate during the Cenozoic era has focused almost exclusively on the possible per- turbation of atmospheric $\mathrm{CO}_{2}$ levels resulting from weathering of silicates, especially in the Himalaya ${ }^{5,6,29,30}$. But Himalayan erosion produces very large $C_{\text {org }}$ fluxes ${ }^{20,31,32}$. Although the hypothesized link between Himalayan silicate weathering and atmospheric $\mathrm{CO}_{2}$ levels remains poorly quantified, our results indicate that increased sedimentary $\mathrm{C}_{\text {org }}$ storage resulting from Neogene Himalayan ero- sion and weathering has had a significantly larger effect on the carbon cycle than silicate weathering, by a factor of $2-3$. Both models of the net change in the global sedimentary Corg reservoir ${ }^{7,26}$ and data from the Himalayan-Bengal system are consistent with the hypothesis that an excess of $\mathrm{C}_{\text {org }}$ burial over weathering acted as a sink for atmospheric $\mathrm{CO}_{2}$ during the Neogene.

Acknowledgements. We thank Patrick Le Fort for providing part of the Himalayan samples and analyses. This study was supported by the CNRS-INSU program ‘Dynamique et Bilan de la Terre-Fleuve et Erosion’.

\section{References}

1. Garrels, R. M. \& Perry, E. A. Cycling of carbon sulfur and oxygen through geologic time. in The Sea 303-336 (1974).

2. Lasaga, A. C., Berner, R. A. \& Garrels, R. M. in The Carbon Cycle and Atmospheric CO2: Natural Variations, Archean to Present (eds Sundquist, E. T. \& Broecker, W. S.) 397-410 (American Geophysical Union, Washington DC, 1985).

3. Berner, R. A. Atmospheric CO2 levels over Phanerozoic time. Science 249, 1382-1386 (1990).

4. Walker, J. C. G., Hays, P. B. \& Kasting, J. F. A negative feed back mechanism for the long-term stabilization of Earth's surface temperature. J. Geophys. Res. 86, 9776-9782 (1981).

5. Raymo, M. E. \& Ruddiman, W. F. Tectonic forcing of late Cenozoic climate. Nature 359, 117-122 (1992).

6. Molnar, P., England, P. \& Martinod, J. Mantle dynamics, uplift of the Tibetan Plateau, and the Indian monsoon. Rev. Geophys. 31, 327-396 (1993).

7. Goddéris, Y. \& Franç, ois, L. M. Balancing the Cenozoic carbon and alkalinity cycles: Constraints from isotopic records. Geophys. Res. Lett. 23, 3743 - 3746 (1996).

8. Einsele, G., Ratschbacher, L. \& Wetzel, A. The Himalaya-Bengal fan denudation accumulation systemduring the past 20 Ma. J. Geol. 104, 163-184 (1996). 
9. France-Lanord, C., Derry, L. \& Michard, A. in Himalayan Tectonics (eds Treloar, P. J. \& Searle, M.) 603-621 (Geol. Soc. Lond., London, 1993).

10. Sayles, F. L. \& Mangelsdorf, P. C. The equilibration of clay minerals with seawater: exchange reactions. Geochim. Cosmochim. Acta 41, 951-960 (1977).

11. Von Damm, K. L., Edmond, J. M., Grant, B. \& Measures, C. K. Chemistry of submarine hydrothermal solutions at $21^{\circ}$ N, East Pacific Rise. Geochim. Cosmochim. Acta 49, 2197-2220 (1985).

12. France-Lanord, C. Chevauchement, mé tamorphisme et magmatisme en Himalaya du Né pal central. Etude isotopique H, C, O. Thesis, Institut National Polytechnique de Lorraine (1987).

13. Beck, R. A., Burbank, D. W., Sercombe, W. J., Olson, T. L. \& Khan, A. M. Organic carbon exhumation and global warming during the early Himalayan collision. Geology 23, 387-390 (1995).

14. Shipboard Scientific Party. Initial Reports Sites 717-718-719 Distal Bengal Fan, Proc. ODP Init. Rep. (Ocean Drilling Program, College Station, TX, 1989).

15. Bouquillon, A., France-Lanord, C., Michard, A. \& Tiercelin, J.-J. in Proc. ODP Sci. Res. (eds Cochran, J. R. et al.) $43-58(1990)$.

16. Derry, L. A. \& France-Lanord, C. Neogene Himalayan weathering history and river $87 \mathrm{Sr} / 86 \mathrm{Sr}$ : Impact on the marine Sr record. Earth Planet. Sci. Lett. 142, 59-74 (1996).

17. Martin, J. M. \& Meybeck, M. Element mass-balance of material carried by major world rivers. Mar. Chem. 7, 173-206 (1979).

18. Sarin, M. M., Krishnaswami, S., Dilli, K., Omayajulu, B. I. K. \& Moore, W. S. Major ion chemistry of the GangaBrahmaputra river system: Weathering processes and fluxes to the Bay of Bengal. Geochim. Cosmochim. Acta 53, 997-1009 (1989).

19. Gardner, R. \& Walsh, N. Chemical weathering oif metamorphic rocks from low elevations in the southern Himalaya. Chem. Geol. 127, 161-176 (1996).

20. France-Lanord, C. \& Derry, L. A. d13C or organic carbon in the Bengal fan: source evolution and transport of C3 and C4 plant carbon to marine sediments. Geochim. Cosmochim. Acta 58, 4809-4814 (1994).

21. Bouquillon, A. Influence continentale et marine dans les sediments C' enozoiques de l'océ an Indien Nord Oriental. Thesis, Université de Lille Flandres-Artois (1987).

22. Berner, R. A. \& Berner, E. Global Environment: Water, Air, and Geochemical Cycles 1-376 (Prentice Hall, Upper Saddle River, NJ, 1994).

23. Michalopoulos, P. \& Aller, R. C. Rapid clay mineral formation in Amazon delta sediments: Reverse weathering and oceanic elemental cycles. Science 270, 614-617 (1995).

24. Milliman, J. D. \& Syvitski, P. M. Geomorphic/tectonic control of sediment discharge ot the ocean: the importance of small mountainous rivers. J. Geol. 100, 525-544 (1992).

25. Shackleton, S. J. \& Hall, M. A. Carbon isotope data from Leg 74 sediments. in Init. Rep. DSDP (eds Moore, T. C. et al.) 613-619 (US Govt Printing Office, Washington, 1984). 
26. Derry, L. A. \& France-Lanord, C. Neogene growth of the sedimentary organic carbon reservoir. Paleoceanography 11, 267-275 (1996).

27. Berner, R. A. \& Canfield, D. A model for atmospheric oxygen over Phanerozoic time. Am. J. Sci. 289, 333-361 (1989).

28. Hedges, J. I. \& Keil, R. G. Sedimentary organic matter preservation: an assessment and speculative synthesis. Mar. Chem. 49, 81-90 (1995).

29. Raymo, M. E. The Himalayas, organic carbon burial, and climate in the Miocene. Paleoceanography 9, 399404 (1994).

30. Caldeira, K. Enhanced Cenozoic chemical weathering and the subduction of pelagic carbonate. Nature 357 , 578-581 (1992).

31. Subramanian, V. \& Ittekkot, V. Carbon transport by the Himalayan rivers. in Biogeochemistry of Major World Rivers, SCOPE (eds Degens, E. T., Kempe, S. \& Richey, J. E.) 157-168 (Wiley, Chichester, 1991).

32. Ittekkot, V. Global trends in the nature of organic matter in river suspensions. Nature 332, 436-438 (1988).

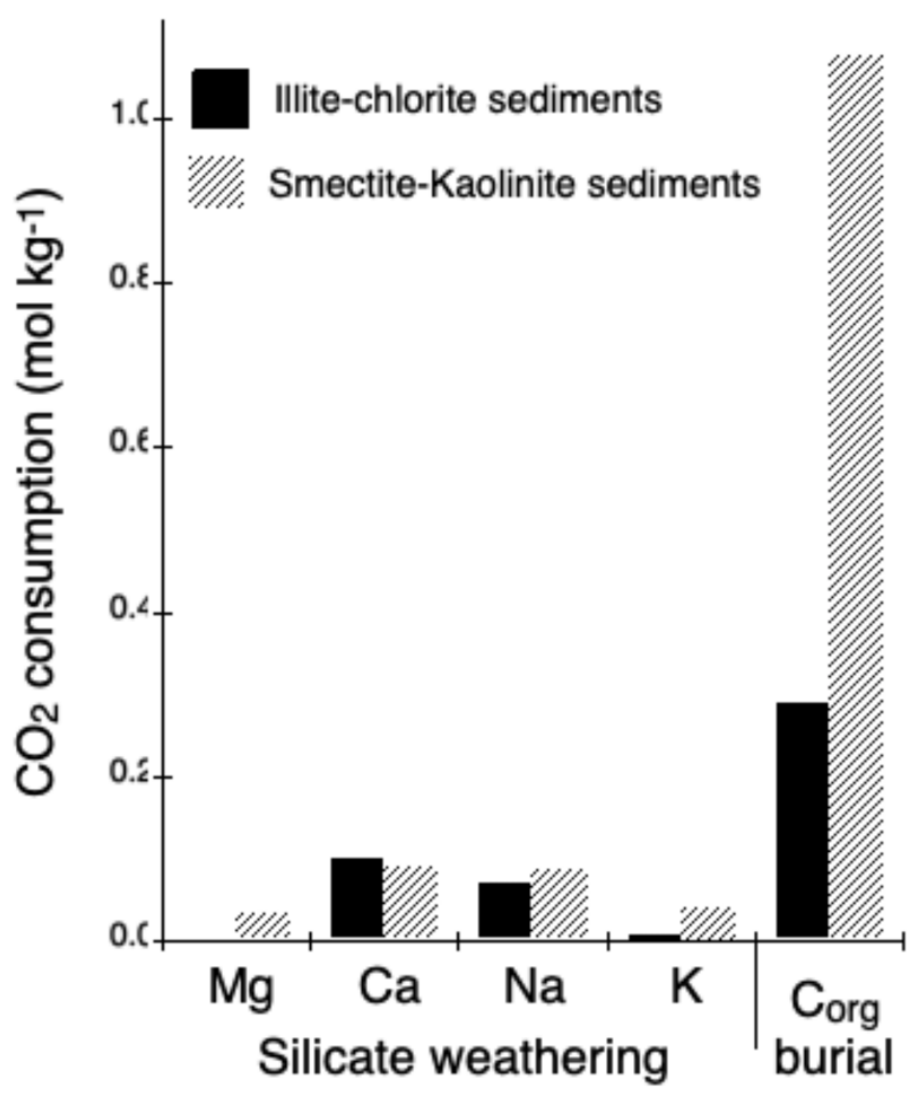


Figure 1 - Consumption of atmospheric $\mathrm{CO}_{2}$ by silicate weathering and burial of organic carbon calculated from the difference between the chemistry of the sediments deposited in the Bengal Fan and their unaltered Himalayan source rocks. Over the Neogene, the effect of silicate weathering is 2-3 times lower than the increase in the amount of Corg in the sedimentary reservoir.

Table 1 Average chemical compositions of the High Himalaya Crystalline $(\mathrm{HHC})$ and decarbonated Bengal Fan sediments

\begin{tabular}{|c|c|c|c|c|c|c|c|c|c|c|c|c|c|c|}
\hline Formation & & $\mathrm{SiO} 2$ & $\mathrm{Al} 2 \mathrm{O} 3$ & $\mathrm{Fe} 2 \mathrm{O} 3$ & $\mathrm{MnO}$ & $\mathrm{MgO}$ & $\mathrm{CaO}$ & $\mathrm{Na} 2 \mathrm{O}$ & $\mathrm{K} 2 \mathrm{O}$ & TiO2 & P2O5 & LO I & Total & Corg \\
\hline $\mathrm{HHC}$ & mean & 71.87 & 13.11 & 4.36 & 0.07 & 1.76 & 1.07 & 2.26 & 3.03 & 0.62 & 0.04 & 1.26 & 99.43 & 0.05 \\
\hline$n=99$ & s.d. & 6.62 & 2.97 & 1.92 & 0.03 & 1.19 & 0.81 & 0.9 & 1.06 & 0.28 & 0.08 & 1.01 & & 0.03 \\
\hline Beng al IC & mean & 62.82 & 16.71 & 6.42 & 0.04 & 2.23 & 0.68 & 1.14 & 3.64 & 0.72 & 0.14 & 5.11 & 99.6 & 0.44 \\
\hline$n=17$ & s.d. & 8.42 & 3.73 & 2.15 & 0.01 & 0.62 & 0.5 & 0.51 & 0.9 & 0.16 & 0.04 & 2.12 & & 0.5 \\
\hline Beng al SK & mean & 54.1 & 17.83 & 9.73 & 0.05 & 2.23 & 0.81 & 0.75 & 2.19 & 1.28 & 0.15 & 10.63 & 99.76 & 1.39 \\
\hline$n=11$ & s.d. & 5.55 & 1.5 & 2.16 & 0.04 & 0.38 & 0.46 & 0.41 & 0.92 & 0.54 & 0.03 & 3.94 & & 0.62 \\
\hline Molar ratio & & Si/AI & & $\mathrm{Fe} / \mathrm{Al}$ & $\mathrm{Mn} / \mathrm{Al}$ & $\mathrm{Mg} / \mathrm{Al}$ & $\mathrm{Ca} / \mathrm{Al}$ & $\mathrm{Na} / \mathrm{Al}$ & $\mathrm{K} / \mathrm{Al}$ & Ti/Al & & & & \\
\hline $\mathrm{HHC}$ & & 2.33 & & 0.21 & 0 & 0.08 & 0.04 & 0.28 & 0.25 & 0.02 & & & & \\
\hline Beng al IC & & 1.59 & & 0.25 & 0 & 0.08 & 0.02 & 0.11 & 0.24 & 0.01 & & & & \\
\hline Beng al SK & & 1.29 & & 0.35 & 0 & 0.08 & 0.02 & 0.07 & 0.13 & 0.02 & & & & \\
\hline
\end{tabular}

Major element analyses were made by inductively coupled plasma optical emission spectroscopy on samples fused with lithium metaborate.

Corg: HHC, n 1/4 21; Bengal, n 1/4 155 (refs 14, 20). 